\title{
ピッチャーの肩関節唇断裂に対する鏡視下手術の治療経験
}

\begin{tabular}{|c|c|c|c|c|c|}
\hline 多 & 胡 & 典 & 郎・原 & & 正 \\
\hline 竹 & 下 & & 満・田 & 村 & 正 \\
\hline 緑 & 川 & 孝 & 二.今 & 井 & \\
\hline 高 & 岸 & 直 & 人 & & \\
\hline
\end{tabular}

\section{Experience with Arthroscopic Operation in the Treatment of Glenoid Labral Tear occurring in a Pitcher}

by

Norio Tago, Masafumi Hara, Mitsuru Takeshita, Shogo Tamura, Kohji Midorikawa, Kazuhiko Imai and Nahoto Takagishi

Department of Orthopaedic Surgery,

School of Medicine Fukuoka University

The case was a 17 -year-old male, southpaw pitcher. Since his age of 9 he had been playing an active part as a pitcher in baseball games throughout his primary, middle and high school days. In Autumn 1987 he experienced pain in his left shoulder while throwing a ball. Because shoulder pain on throwing a ball continued he was admitted to our department ward in May 1988. No abnormalities were noted on plain x-ray and arthrography, but arthroscopic examination revealed a tear of glenoid labrum in its postero-superior portion and an abnormal bandle which arose posterior to the long biceps tendon and attached to the joint capsule above. These lesions, being judged as the cause of the pain, were resected. Postoperative management which consisted of ROM exercise and muscle training supplemented with a pitching rehabilitation program using PNF technique, was initiated on the 2nd postoperative day. 6 weeks postoperatively the patient returned to his work as a pitcher and now, 6 months after operation, he is playing baseball without experiencing any pain on pitching.

\section{はじめに}

投球による肩関節障害の中でも, 活動の場が high level で, しかもポジションがピッチャーであった場 合, 治療および復帰はよりきびしくなる. 今回, 我々 はピッチャーで関節唇断裂の症例を経験し，関節鏡視 下手術により侵襲をおさえ, 後療法に重点を置き, 早 期にピッチャーとして復帰させえたので, ここに症例 を報告する。

\section{症例}

17才 男性 左投手.

既往症・家族歴：特記すべき事項はない.
現病歴：9 」より野球をはじめ, 小中高校を通じて pitcher として活躍していた．昭和62年秋頃より投球 時に左肩痛が出現した。 なお，その痛みは cocking phase から acceleration phaseにかけての痛みで あった。近医整形外科受診し, 理学療法を受け一時症 状の軽快を見た。しかし, 昭和63年 3 月頃より再度同 様の症状が出現し, 徐々に増悪していった. そのため, 投球を中止した。

同年 5 月 6 日当科受診し，精査および加療目的にて 同年 5 月 10 日当科入院となる.

入院時所見：視診において, 左僧帽筋・大胸筋・菱形 筋の筋萎縮を認め, また左肩甲骨は右に比し, 約 $2 \mathrm{~cm}$ 下降していた (図 1 )。可動域では, 水平内旋 (右 $100^{\circ}$ 


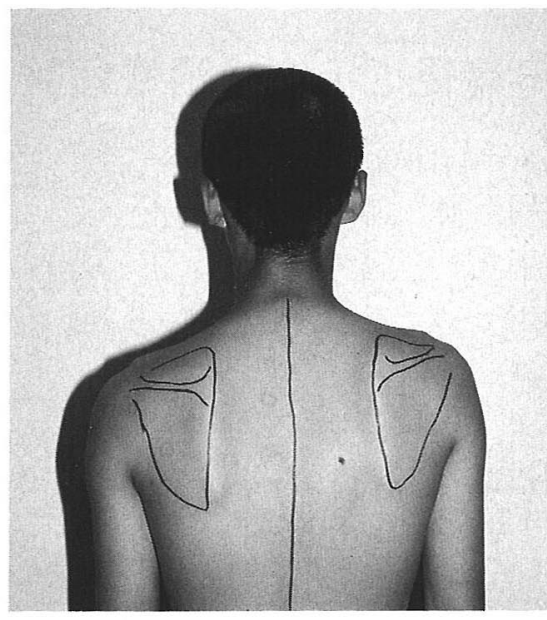

図 1 入院時写真：左肩甲骨は右に比ベ， 約 $2 \mathrm{~cm}$ 下降.
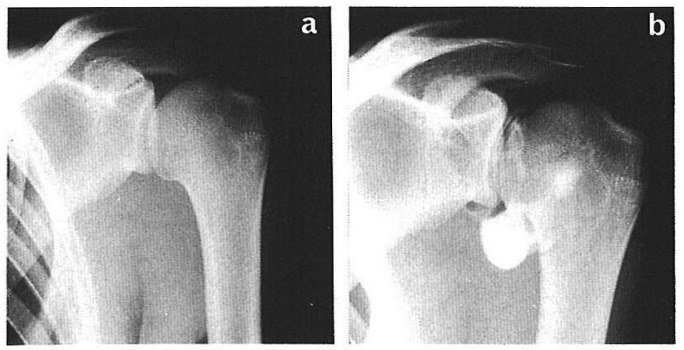

図 2 a. 単純レ線.

b. 関節造影: middle gleno-humeral ligament の損傷が疑われる.

左 $80^{\circ}$ ), 水平外旋 (右 $120^{\circ}$, 左 $\left.140^{\circ}\right)$ に左右差を認めた ものの，その他はほとんど正常可動域であった，圧痛，

運動時痛, apprehension test, impingement testは それぞれ陰性で，また，各方向の関節不安定性もみら れなかった，関節内を局麻剤で Block した所，投球時 痛の消失をみた。この事で病巣は，関節内にあると判断 した。単純レ線では Bennet 病変は認められなかった (図 2 a).また, 関節造影では middle gleno-humeral ligament の損傷が疑われる像を呈していたが5), Bankart 病変は認められなかった（図 $2 \mathrm{~b}$ )。術前評価は日整会 肩関節治療判定基準で87点であった。

関節鏡所見：全身麻酔下で行なった，後方穿刺と前方 穿刺の鏡視所見は middle gleno-humeral ligament は 低形成を呈していたが, 正常と判断した ${ }^{3)}$. inferior
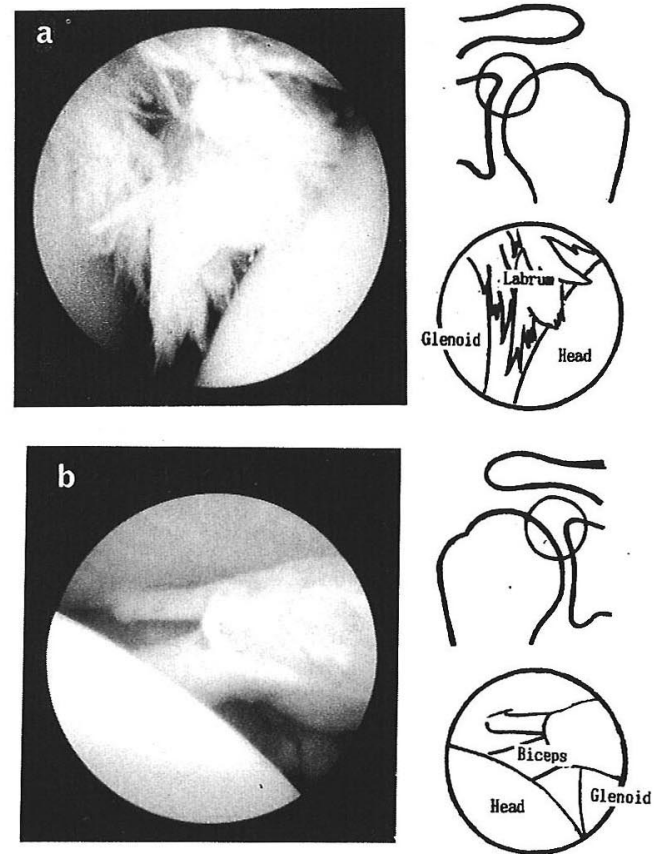

図 3 関節鏡視所見

a. 前方穿刺：前上方の関節唇は自蓋から断裂剝 離している.

b. 後方穿刺：長頭腱起始部の後方より異常索状 物が起こり, 前方へ走り上方の関節包に付着 している。

gleno-humeral ligament の走行及びその発達は正常 であった。また前上方の関節唇は剝離所見は認められ なかったが，後上方の関節唇は䝿から断裂剝離して いた (困 $3 \mathrm{a}$ )。長頭腱の走行や結節間溝部には異常は なかった。しかし, 長頭腱起始部の後方より異常索状 物が起こり，前方へ走り上方の関節包に付着していた (図 3 b ). そこで術前にあった疼痛が断裂関節唇によ る可能性もあると判断して，鏡視下に，この断裂関節 唇の部分切除，これに加え前述の異常索状物を切除 した。

後療法及び術後経過：本人の強い希望もあり, 高校野 球県大会出場に照準を合わせ $\mathrm{Pappas}^{8)}$ のプログラム をもとにして，独自のプログラムをたててみた。術後 2 日目より可動域訓練を開始し，7 日目には可動域は ほほ正常となり，また術前に存在した肩甲骨の下降も 改善された. そこで P.N.F.) (Proprioceptive Neuromuscular Facilitation) technique 含めた筋力強化 
訓練を開始した。 その後, 20日目より shadow pitching 及び距離 $10 \mathrm{~m}$ で投球練習（山なりで）を開始し， 25日目には畦間で，30日目には $45 \mathrm{~m}$ と投球距離を延ば し，40日目には全力投球できる様になり，実践的な pitching 練習に入った. 結果的には, 術後60日目にし てエースとして投球時痛なく高校野球県大会に出場を 果たした. 術後 6 ケ月の現在, チームのエースとして 活躍している.

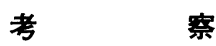

本症例は, 投球時の疼痛に対する検査目的で入院し た。単純レ線及び関節造影では，いわゆる野球肩の病 因となるBennet 病変, Bankart 病変等は見られな かった.しかし，関節鏡施行し，後上方の関節唇断裂 と長頭腱後方より起こり上方の関節包に付着する異常 索状物があり, 切除したところ, 術後疼痛消失した。 また，術後 1 週間で術前にあった肩甲骨の下降も改善 した.そこでいくつかの問題点について考えてみる. まず，関節唇断裂について考えてみる. Andrew ら は, 投球選手 73 症例の肩関節の関節唇断裂について報 告している. その中で, 前上方部のものが $60 \%$, 後上

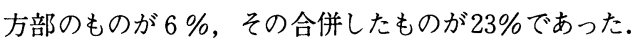
上方関節唇断裂が大半を占めており, その中でも, 本 症例は比較的頻度の少ない後上方部のみの断裂であっ た. Andrew は, 前上方部関節唇断裂の mechanism について biceps が biceps labrum complex (B.L. C. ）を牽引することで生じると述べているが本症例の ような後上方部の関節唇に単独に断裂を生じさす mechanism については詳しく述べていない. 疼痛の本 態を考えた場合, 本症例は, cocking phase から acceleration phaseにかけての疼痛があり，一般的に は，いわゆる第二肩関節の impingement syndrome 様 の疼痛である.しかし関節内の局麻剤注入により，投 球時疼痛が消失している点，また鏡視所見で腱板関節 面断裂がない点を考えるに，この後上方関節唇以外に 病的所見がなく術後疼痛が消失している点からも, こ の断裂が本症例の病態と考えざるを得ない.

次に本症例の後上方関節唇断裂の mechanism につ いて考えてみる．まず索状物が本病態と関係があると 仮定してみる，索状物は，村田 ${ }^{6)}$ 長野 ${ }^{7)}$ の詳しい関節 内解剖にも記載のないものであり，不明なものである が,これが Biceps の後方から生じている点, 投球時
何らかの毫引力が後上方の関節唇に加わり，まるで Andrew ${ }^{11} の$ biceps labrum complex (B.L.C.)の如 く作用して骨頭と臼蓋の間に関節唇が impinge して断 裂が生じたと考えてみた。

次に肩甲骨の下降が術後 1 週で改善された点につい て考えてみる。

肩に障害を有する野球選手はいわゆる“野球肩”の 中で一般には肩関節及び肩甲骨周囲筋の拘縮のため肩 甲骨の下降を生じさす事がある，その改善のためには 長期に渡る理学療法を要するが本症例の場合約 1 週間 で改善が見られた点, 筋の拘縮とは考えがたい.

原) は, 関節内索状物が疼痛を生じさす mechanism を述べ，その疼痛緩和のため自然に肩甲骨の内転を生 じると述べている.

本症例の場合，切除された索状物もしくは断裂関節 唇が関与していると考えられるがそのメカニズムは不 明である。

次に後療法について検討してみる. 投球動作は決し て肩だけの運動ではなく上肢, 体幹, 下肢の協調運動 によってなされる.したがって，いずれの部分に障害 があってもその協調性は失われ，また肩単独の障害で もその周囲筋の筋協調性が失われる. その結果 ball の speed と control を損なうことになる. そこで, 後療 法にあたっては，この筋の協調性を重視する必要があ る. $\mathrm{Pappas}^{8)}$ は投球における肩の後療法のゴールとし て, (1)正常な ROM の回復, (2)正常な筋協調性の回復, (3)筋力と耐久力の増強, そしてこれが得られた時点で の段階的投球練習をあげている.

本症例の場合, 先に述べたごとく P.N.F.technique を含めたプログラムを立て, 多方向運動の筋力強化を 計り，筋協調性獲得を重視したことが，良好な結果に つながったと考えられた.

\section{ま と め}

我々は, ピッチャーで, 関節鏡視にて後上方の関節 唇断裂と異常索状物を認めた症例を経験したので, 若 干の考察を加え報告した.

\section{参考文 献}

1) Andrew, JR, et al: Glenoid labrum tears related to the long head of the biceps. Am J.Sports Med, 13: 337-341, 1985. 
2) Eric, V :PNF－神経筋促通手技. 医歯薬出版株式 会社. 東京, 1985 .

3）原 正文：肩関節疾患の関節鏡検查に関する解剖学 的および臨床的研究. 医学研究, $57: 35-49,1987$.

4）原 正文：関節内索状物切除後に随意性肩関節脱臼 が消失した一症例. 肩関節, $12: 152-156,1988$.

5）緑川孝二他：反復性肩関節脱臼のレ線検討. 整形 · 災害外科, $37: 259-263,1988$.

6）村田 敬：肩関節付属滑液軎の研究. 金沢大学医学 部解剖学教室業績. $45: 1-32,1953$.

7）長野実雄：肩関節付近の滑液輁について第 1 編，第 2 編, 第 3 編. 鹿児島大学医学雑誌, $9: 60-118,1957$.

8) Pappas, AM, et al : Rehabilitation of the pitchig shoulder. Am J.Sports Med. 13:223-235, 1985.

筫問豊労災病院 井上博

1) 筋萎縮の原因は.

2 ）術後いつ頃に筋萎縮は回復したか.

\section{解 答}

福岡大学 多胡 典郎

肩周囲の筋萎縮は, 約半年間の投球中止によって生 じた disuse atrophy と考えられる.
䓄問熊本機能病院 浦田 節雄

(1) Labrum の lesion は肩不安定性が base にあって おこるものでしょうか. そうではなければなにか他 に原因があるのでしょうか.

(2) 関節鏡でどのくらい Synovium がとれますか.
解 答
福岡大学 原
正文

関節不安定性を有している選手の場合, 関節唇断裂 が生じやすいと考える.

\section{貿 問}

長崎大学 伊藤信之

後上方の関節唇に異常があったようですが, 術前所 見で関節鏡所見が予想出来ましたでしょうか.

\section{解 答福岡大学 原 正文}

術前に，臨床的に本病㦔を把握する事は出来ず，関 節鏡によってはじめて把握し得た．また，前方と後方 穿刺による鏡視は，必須である. 